\title{
Butorphanol in labour analgesia: A prospective cohort study
}

\section{Doğum sancısı analjezisinde butorfanol: Bir prospektif kohort çalışma}

\author{
Ajay Halder ${ }^{1}$ Rachana Agarwal ${ }^{2}$ \\ 'Department of Obstetrics and Gynaecology, Christian Medical College, Vellore, India \\ ${ }^{2}$ Department of Obstetrics and Gynaecology, Sarojini Naidu Medical College, Agra, India
}

\section{Abstract}

Objective: Parenteral opioids can be administered with ease at a very low cost with high efficacy as labour analgesia. However, there are insufficient data available to accept the benefits of parenteral opioids over other proven methods of labour analgesia. Butorphanol, a new synthetic opioid, has emerged as a promising agent in terms of efficacy and a better safety profile. This study investigates the effect of butorphanol as a labour analgesia to gather further evidence of its safety and efficacy to pave the way for its widespread use in low resource settings.

Material and Methods: One hundred low risk term consenting pregnant women were recruited to take part in a prospective cohort study. Intramuscular injections of butorphanol tartrate $1 \mathrm{mg}$ (Butrum 1/2mg, Aristo, Mumbai, India) were given in the active phase of labour and repeated two hourly. Pain relief was noted on a 10-point visual pain analogue scale (VPAS). Obstetric and neonatal outcome measures were mode of delivery, duration of labour, Apgar scores at 1 and 5 minutes and Neonatal Intensive Care Unit admissions. Collected data were analysed for statistically significant pain relief between pre- and post-administration VPAS scores and also for the incidence of adverse outcomes.

Results: Pain started to decrease significantly within 15 minutes of administration and reached the nadir (3.08 SD0.51) at the end of two hours. The pain remained below four on the VPAS until the end of six hours and was still significantly low after eight hours. The incidence of adverse outcomes was low in the present study.

Conclusion: Butorphanol is an effective parenteral opioid analgesic which can be administered with reasonable safety for the mother and the neonate. The study has the drawback of lack of control and small sample size.

(J Turkish-German Gynecol Assoc 2013; 14: 221-4)

Key words: Labour analgesia, butorphanol, visual pain analogue scale

Received: 06 March, 2013

Accepted: 23 September, 2013
Özet

Amaç: Parenteral opioidler doğum sancısı analjezisinde yüksek etkinlikle, çok düşük bir maliyetle, kolaylıkla uygulanabilir. Bununla birlikte, doğum sancısı analjezisinde diğer kanıtlanmış metotlara göre parenteral opioidlerin faydalarını kabul etmek için ulaşılabilir yeterli veri bulunmamaktadır. Butorfanol, yeni bir sentetik opioiddir, etkililik ve daha iyi bir güvenlilik profili açısından ümit veren bir ajan olarak ortaya çımıştır. Bu çalışma, düşük kaynaklı ortamlarda yaygın kullanımının yolunu açmak için güvenlilik ve etkililiği hakkında daha fazla kanıt toplamak amacıyla doğum sancısı analjeziği olarak butorfanolün etkisini araştırmaktadır

Gereç ve Yöntemler: Düşük risk vadeden 100 hamile kadın prospektif kohort çalışmasında yer almak üzere kaydedildi. Butorfanol tartarat $1 \mathrm{mg}$ kas içi enjeksiyonlar (Butrum 1/2mg, Aristo, Mumbai, Hindistan) doğum sancısının aktif fazında verildi ve iki saatte bir tekrarlandı. Ağrı azalması 10 maddelik görsel ağrı analog skalası (VPAS) ile kaydedildi. Obstetrik ve yenidoğan akibet ölçümleri; doğum şekli, doğum sancısının süresi, 1. ve 5. dakikadaki Apgar skorları ve Yenidoğan Yoğun Bakım Ünitesine kabul durumu idi. Toplanan veriler uygulama öncesi ve sonrası VPAS skorlanı arasında ağn gidermede istatistiksel anlamlılık açısından ve ayrıca advers sonuçların insidansı için analiz edildi.

Bulgular: Ağnı uygulamanın 15 dakikası içinde önemli ölçüde azalmaya başladı ve iki saatin sonunda çok az düzeye (3.08 SD 0.51) ulaştı. Ağrı altı saatin sonuna kadar görsel ağrı analog skalasında (VPAS) dördün altında kaldı ve sekiz saat sonra hâlâ oldukça düşüktü. Advers sonuç insidansı bu çalışmada düşüktü.

Sonuç: Butorfanol anne ve yenidoğan için makul güvenlilik ile uygulanabilen etkili bir parenteral opioid analjeziktir. Bu çalışma, kontrol yokluğu ve örneklem boyutunun küçük olması dezavantajına sahiptir. (J Turkish-German Gynecol Assoc 2013; 14: 221-4)

Anahtar kelimeler: Doğum sancısı analjezisi, butorfanol, görsel ağrı analog skalası

Geliş Tarihi: 06 Mart 2013

Kabul Tarihi: 23 Eylül 2013

\section{Introduction}

Pain experienced by women during labour is considered the worst kind of physical suffering that a human being can undergo in their lifetime (1). Labour analgesia has much to offer in the management of pain in these women. Several non-pharmacological methods have been in use for a long time and still find their place in modern medicine with some proven benefits (2-8). Pharmacological methods include options like inhaled analgesic gases, opioids and non-opioid drugs, local anaesthetic neuronal block like pudendal and paracervical block, and epidural anaesthesia, including combined spinal epidural (CSE).

Epidural analgesia, including combined spinal epidural and inhalational anaesthesia, has been proven to be beneficial (9), but has side effects like nausea, vomiting and increased 
operative deliveries (10). The major factor which limits their use is the costs involved. The data are insufficient to accept the benefits of parenteral opioids over other proven methods of labour analgesia (9). However, the low cost and ease of administration of parenteral opioids has kept the interest of researchers alive as they are the only effective alternative feasible in low resource settings. Butorphanol, a new synthetic opioid which has a partial agonistic action, has emerged as a promising agent in terms of efficacy and better safety profile. This study investigates the effect of butorphanol as labour analgesia to gather further evidence of its safety and efficacy to pave the way for its widespread use in low resource settings.

\section{Material and Methods}

The study was conducted in the labour ward of a medical college hospital in the western part of India where consenting low risk term (37 to 41 weeks) pregnant women between the ages of 19 and 35 years were consecutively recruited for the study. Women with known medical risk factors like hypertension, diabetes, obesity (BMI>30), hypothyroidism, asthma, epilepsy, psychiatric disorders, cardiac or renal diseases, or women with anticipated obstetric complications like breech, multiple pregnancies, small for gestation foetus, cephalopelvic disproportion, previous uterine surgeries, caesarean section etc. were excluded. Women in advanced labour who were not able to consent were also excluded. Detailed information about the drug, its benefits and possible side effects were explained to the women before their consent was sought once they came to the labour room for admission either in spontaneous or induced labour. Intramuscular butorphanol tartrate $1 \mathrm{mg}$ was administered at the onset of active labour. Meticulous examination and recording of the vital parameters were done before and every 30 min after the administration. Pain relief was assessed with the 10 point visual pain analogue scale (VPAS) (Table 1). Progress of labour was monitored partographically and foetal surveillance was performed with continuous cardiotocography. The Foetal Heart Rate traces were categorised into Normal, Suspicious and Pathological according to set guidelines (11). Further obstetric interventions were done according to the standard protocols. Injections were repeated after 2 hours on demand, but not within 2 hours of anticipated delivery. Women were monitored for 2 hours in the labour ward after vaginal delivery and in the recovery room after caesarean section. Neonates were evaluated by the on duty neonatologist at delivery and Apgar scores at 1 and 5 minutes were noted. The conditions of the mother and baby were followed until discharge.

Table 1. Ten point visual pain analogue scale vs. rupee scale

\begin{tabular}{|l|l|l|}
\hline $\begin{array}{l}\text { Visual Pain } \\
\text { Analogue Scale }\end{array}$ & $\begin{array}{l}\text { Rupee } \\
\text { Scale }\end{array}$ & Degree of Pain \\
\hline $0-3 \mathrm{~cm}$ & 4 ana & Minimal pain \\
\hline $4-6 \mathrm{~cm}$ & $4-8$ ana & Mild pain but comfortable \\
\hline $7-8 \mathrm{~cm}$ & $8-12$ ana & Moderate pain with discomfort \\
\hline $9-10 \mathrm{~cm}$ & $12-16$ ana & Severe pain with severe discomfort \\
\hline
\end{tabular}

Data were collected in a Microsoft Excel (Excel 2007, Microsoft Corporation, Washington, USA) work sheet and analysed for statistical significance. Institutional review board and ethical committee clearance were obtained for the study. The study was funded by the Institute's research grants.

\section{Results}

A total of 136 women were approached to take part in the study. Twenty eight women did not fulfil the eligibility criteria and eight women declined to participate. The study was concluded when 100 women were recruited (Figure 1). The majority of women who participated in the study were between the ages of 19 and 25 years (76\% vs. 24\%) with an almost equal number of primipara and multipara (54\% vs. 46\%). In ninety percent of cases, normal vaginal delivery could be achieved with another $8 \%$ of women having instrumental vaginal delivery (forceps and vacuum delivery). Only two women (2\%) underwent caesarean section for non-reassuring foetal status in early labour. Table 2 shows the average duration of labour (from onset of active stage to end of second stage of labour) in each mode of delivery. Eighty six percent of women were given only two doses of butorphanol, 13\% were given three doses and only one woman was given a fourth dose. The pre-injection mean VPAS was 8.15 SD 2.04. Pain started to decrease significantly within 15 minutes of administration and reached the nadir (3.08 SD 0.51) at the end of two hours. The pain remained below four on the VPAS for six hours and was still significantly low after eight hours. Figure 2 depicts pre-administration and the relief of pain after periodic injections of butorphanol intramuscularly on VPAS.

There was a significant reduction in the mean pulse rate $(92.00$ vs. 76.88 per minute; $p=0.001)$, mean systolic blood pressure (122.06 vs. $133.53 \mathrm{~mm}$ of $\mathrm{Hg} ; \mathrm{p}=0.001$ ) and mean respiratory

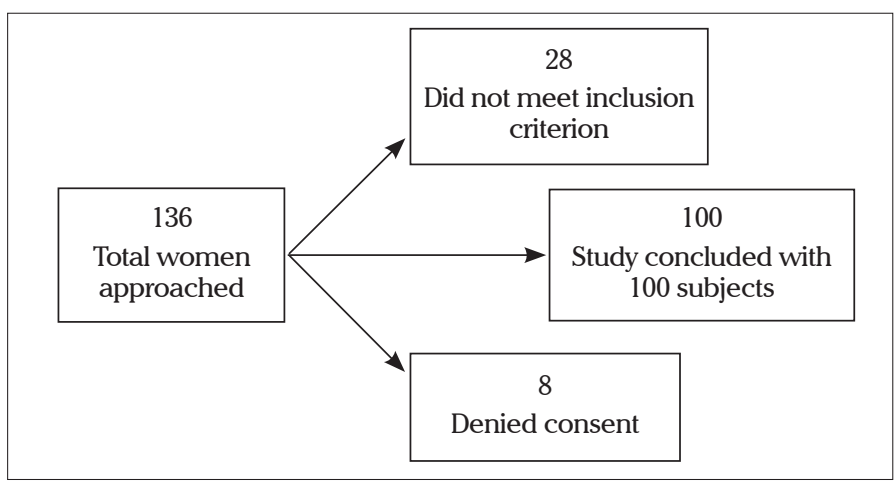

Figure 1. Flowchart for patient recruitment

Table 2. Duration of labour

\begin{tabular}{|l|c|c|}
\hline Mode of Delivery & $\begin{array}{c}\text { Number of } \\
\text { Cases }\end{array}$ & $\begin{array}{c}\text { Mean Duration } \\
\text { of Labour (hrs) }\end{array}$ \\
\hline Normal vaginal delivery & 39 & 5.22 \\
\hline Vaginal with episiotomy & 51 & 6.99 \\
\hline $\begin{array}{l}\text { Instrumental delivery } \\
\text { (Forceps \& Vacuum) }\end{array}$ & 8 & 7.15 \\
\hline Caesarean section & 2 & 8.23 \\
\hline
\end{tabular}


rate (19.06 vs. 15.48 per minute; $\mathrm{p}=0.001)$. A decrease in the mean diastolic blood pressure did not reach statistical significance. Thirteen percent of women experienced minor side effects like nausea and vomiting. Three women had prolonged sedation for more than four hours after delivery but did not require any ventilator support or antidote (naloxone). No incidence of hypersensitivity to drug or respiratory depression was seen in the study population.

The Apgar scores of the neonates at one and five minutes of life are depicted in Table 3. Nine neonates had Apgar scores of 6 or below at 1 minute and by the $5^{\text {th }}$ minute only two neonates had an Apgar score of 6 or below. Ninety eight percent of the neonates had Apgar scores of more than 6 by the end of 5 minutes. Seven neonates required ICU admission for observation due to meconium stained liquor (5 cases) and transient tachapnoea of newborn ( 2 cases). No case of hypoxic ischemic encephalopathy or neonatal death was seen in the current cohort until discharge from the hospital. The relationship between the cardiotocographic observations and the neonatal outcome is shown in Table 4.

\section{Discussion}

Pain of labour often results in excessive maternal suffering, marked maternal hyperventilation and increased oxygen demand. The natural response to labour pain results in increased catecholamine levels leading to uterine hypoperfusion, foetal hypoxia and acidosis (1). For many years, potent

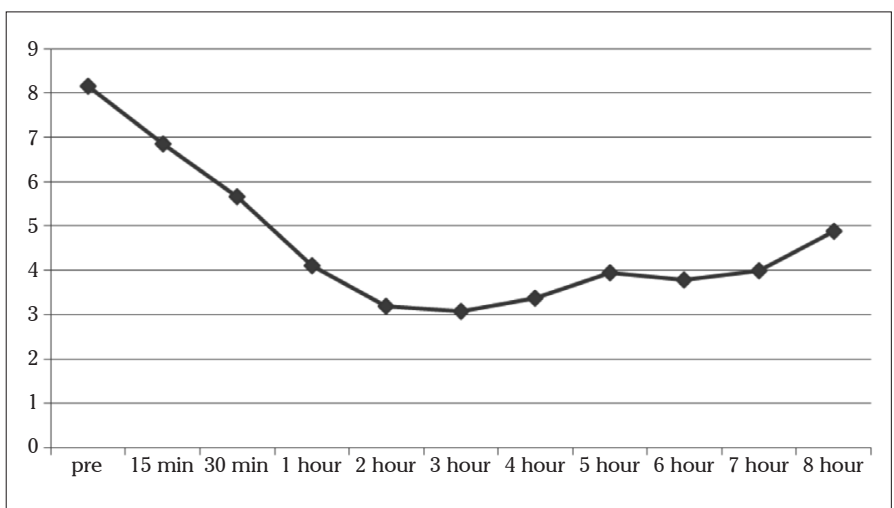

Figure 2. Pain on the Visual Pain Analogue Scale with time

Table 3. Apgar scores

\begin{tabular}{|l|c|c|}
\hline Apgar Score & At $\mathbf{1}$ in & At $\mathbf{5}$ min \\
\hline$>6$ & 91 & 98 \\
\hline 6 or less & 9 & 2 \\
\hline
\end{tabular}

Table 4. Cardiotocography observations and neonatal outcome narcotic agents were used for post-operative pain relief and it seemed as though analgesia, emesis, respiratory depression and addiction potential were inseparable. Diazepam, a benzodiazepine, has been uncommonly used in labour for sedation and anxiolysis. The principle adverse effects of hypotonia, lethargy, decreased feeding and hypothermia in the neonate limits its use (12-13). Opioids commonly used for labour analgesia are meperidine, morphine, fentanyl, nalbuphine and butorphanol. All of these are potent analgesics, but fear of the above side effects may restrict their widespread use. Butorphanol tartrate is a potent analgesic with partial agonist action with minimum side effects (14). Although in radioligand binding studies, butorphanol binds to both $\mu$ and $\kappa$ (kappa) opioid receptors, most of the observed behavioural, pharmacological, and therapeutic effects appear to be due to its lower efficacy agonist actions at $\mu$ opioid receptors (15). The $\kappa$ agonist effects may be revealed in an opioid-dependent or opioid-receptor challenged organism. The major advantage is its low toxicity and low potential for abuse (16). Butorphanol tartrates have been previously studied by several anaesthetists in the context of labour analgesia and have been found to be effective. Maduska et al. (17) compared butorphanol with mepridine in a double-blind randomised control trial and found it to be equally effective and safe. Efficacy and safety of butorphanol in labour analgesia was further established by the works of Atkinson et al. (18) and Quilliganet et al. (19). The former compared butorphanol with fentanyl in labour analgesia; they found that butorphanol was more effective in relieving pain early and was equally effective regarding the safety of the mother and newborn. The latter investigators found an increased foetal heart rate in the butorphanol group which was not associated with any adverse neonatal outcome. In a comparison with nalbuphine, pentazocine and butorphanol, acidotic changes in the foetus were most marked with pentazocin, moderate with nalbuphine and minimal with butorphanol (20). Reedy et al. (21) showed that butorphanol was seven times more potent than morphine for pain relief in the post-operative period following major surgeries. In the present study, there was significant reduction of pain when compared using the VPAS score before and after the administration of butorphanol, which became significant within 15 minutes of administration. The maximum effect was seen by the end of the first hour and this action was sustained for five more hours. Repeated injections were required in 14\% of cases. Butorphanol was not found to delay labour. The mean duration of labour was not prolonged in each mode of delivery. There was also no undue increase in the number of caesarean deliveries or instrumental vaginal deliveries. The decrease in the mean pulse rate, respiratory rate and systolic blood pres-

\begin{tabular}{|l|c|c|c|c|c|}
\hline \multirow{2}{*}{ FHR Trace Categories } & \multirow{2}{*}{$\mathbf{n}=\mathbf{1 0 0}$} & At 1 min & At 5 min & \multicolumn{2}{|c|}{ NICU Admission } \\
\cline { 3 - 6 } & 63 & 3 & nil & 2 & hours \\
\hline Normal & 32 & 5 & 2 & 4 & nil \\
\hline Suspicious & 05 & 1 & nil & 1 & nil \\
\hline Abnormal & & & & nil \\
\hline
\end{tabular}


sure was considered a reflection of anxiety alleviation and was deemed a welcome sign. This probably did not reflect any direct effect of the drug.

During intrapartum foetal monitoring, no increased incidence of foetal heart rate abnormalities was seen. Nine neonates had low Apgar scores at 1 minute, which improved by 5 minutes in all but 2 infants who were admitted to the intensive care unit and discharged after observation.

Randomisation was not desired as not offering pain relief by giving placebo was considered unethical. The study group consisted of a small subset of women in labour and the safety of the drug in high risk women needs to be established. However, the concept of risk identification and referral of at risk antenatal mothers to higher centres provides a broader applicability of parenteral butorphanol at peripheral hospitals.

In conclusion, modern day obstetric analgesia has taken centre stage in the management of labouring mothers. Epidural analgesia has become an inseparable part of labour in western countries and resourceful centres in India too. Its safety and efficacy have been proven beyond doubt. It allows near complete analgesia with preserved patient mobility. Side effects are negligible in the hands of expert anaesthetists and obstetricians. However, it is dependent on an elaborate setup and extra personnel for administration and monitoring, maintaining asepsis, closer foetal surveillance and 24 hour operative and intensive care services for obstetric and anaesthetic emergencies, thereby increasing the cost exponentially. In this situation, parental opioids emerge as an effective and low cost alternative in resource-poor settings where anaesthesia and operating theatre facilities are more restrained or even absent. Several research papers including the present paper have shown high potency with better safety profiles among newer synthetic opioids. Butorphanol has higher potency and fewer side effects even in labouring mothers and their neonates, with a low chance of dependency. Although a controlled drug, it can be distributed and stored without special arrangements. If pain relief during labour is given priority at the policy level, butorphanol can serve as a low cost, safe and effective method for the poorest of women delivering at remote places. Therefore, no mother should be denied pain relief in want of resources and leaving her to suffer the worst possible pain when other members of the family are celebrating.

Ethics Committee Approval: Ethics committee approval was received for the study.

Informed Consent: Informed consent was received from the participants of this study.

Peer-review: Externally peer-reviewed.

Author contributions: Concept-A.H.;Design-A.H.; SupervisionA.H., R.A.; Resource - A.H., R.A.; Materials - A.H., R.A.; Data Collection\&/or Processing - A.H., R.A.; Analysis\&/or Interpretation-A.H., R.A.; Literature Search-A.H., R.A.; WritingA.H., R.A.; Critical Reviews - A.H., R.A.

Conflict of Interest: The authors declared no conflict of interest.

Financial Disclosure: The authors declared that this study received no financial support.

\section{References}

1. Melzack R. The myth of child birth. Pain 1984; 19: 321-37 [CrossRef]

2. Landolt AS, Milling LS. The efficacy of hypnosis as an intervention for labor and delivery pain: a comprehensive methodological review. Clinical psychology review 2011; 31: 1022-31. [CrossRef]

3. American Medical Association. Reader's Guide to Alternative Health Methods. Milwaukee, WI: American Medical Association, 1993.

4. Moneta J, Okninska A, Wielgos M, Przybos A, Szymusik I, Marianowski L. Patient's preferences concerning the course of labor. Ginekologia Polska 2001; 72: 1010-8.

5. Vickers A, Zollman C. ABC of complementary therapies: massage therapies. BMJ 1999; 319: 1254-7. [CrossRef]

6. Pomeranz B, Stux G. Scientific Bases of Acupuncture. Berlin: Springer-Verlag, 1989. [CrossRef]

7. Stevensen CJ. The psychophysiological effects of aromatherapy massage following cardiac surgery. Complementary Therapies in Medicine 1995; 2: 27-35. [CrossRef]

8. Simkin P, Bolding A. Update on nonpharmacologic approaches to relieve labor pain and prevent suffering. Journal of Midwifery \& Women's Health 2004; 49: 489-504. [CrossRef]

9. Jones L, Othman M, Dowswell T, Alfirevic Z, Gates S, Newburn M, et al. Pain management for women in labour: an overview of systematic reviews. Cochrane Database of Systematic Reviews 2012, Issue 3. Art. No.: CD009234. DOI: 10.1002/14651858.CD009234.pub2. [CrossRef]

10. Anim-Somuah M, Smyth R, Howell C. Epidural verss non-epidural or no analgesia in labour. Cochrane Database of Systematic Reviews 2005, Issue 4. DOI: 10.1002/ 14651858.CD000331.pub2

11. http://www.nice.org.uk/nicemedia/pdf/efmguidelinenice.pdf

12. Gee JE, MeyerJ, Hailey DM. Diazepam in labor; Its metabolism and effect on the clinical condition and thermogenesis of newborn. BMJ 1973; 4: 251-5. [CrossRef]

13. Scher J,Hailey DM, Beard RW. The effect of diazepam administered to mothers during labor on temperature of neonates. Arch Dis Child 1972; 47: 107-10. [CrossRef]

14. Rosow CE. Butorphanol in perspective. Acute Care 1988; 12 Suppl 1: 2-7.

15. Chang KJ, Cuatrecasas P. Heterogeneity and properties of opiate receptors. Fed Proc 1981; 40: 2729-34.

16. Ameer B, Salter FJ. Drug therapy reviews: evaluation of butorphanol tartrate. J Hosp Pharm 1979; 36: 1683-91.

17. Maduska AL, Hajghassemali M. A double-blind comparison of butorphanol and meperidine in labour: maternal pain relief and effect on the newborn. Can Anaesth So J 1979; 25: 398-404. [CrossRef]

18. Atkinson BD, Truitt LJ, Rayburn WF, Turnbull GL, Christensen HD, Wlodaver A. Double-blind comparison of intravenous butorphanol (Stadol) and fentanyl (Sublimaze) for analgesia during labor. Am J Obstet Gynecol 1994; 171: 993-8. [CrossRef]

19. Quilligan EJ, Keegan KA, Donahue MJ. Double-blind comparison of intravenously injected butorphanol and meperidine in parturients. Int J Gynaecol Obstet. 1980; 18: 363-7.

20. Wahab SA, Askalani AH, Amar RA, Ramadan ME, Neweigy SB, Saleh AA. Effect of some recent analgesics on labor pain and maternal and fetal blood gases and pH. Int J Gynaecol Obstet 1988; 26: 75-80. [CrossRef]

21. Reedy ME, Morris LE, Brown DL, Snow D, Koehl M, Stone CK. Double-blind comparison of butorphanol and morphine in patientcontrolled analgesia. Acute Care 1988; 12 Suppl 1: 40-6. 